\title{
An Analysis of the Technical Efficiency of Non Motorized Small Scale Shrimp Fishers in the Coastal Areas of Delta State, Nigeria
}

\author{
Wategire, B. B. \\ Ike, P. C. \\ Department of Agricultural Economics, Delta State University, Asaba Campus, Asaba, Delta State, Nigeria
}

\section{Doi:10.5901/mjss.2015.v6n1p285}

\begin{abstract}
The study examined the technical efficiency of small scale shrimp fishers, the socio-economic characteristics and specific factors that affect the efficiency level, and the costs, revenues and profit structures of non motorized small scale shrimp fishers in the coastal areas of Delta State. The study was based on primary data obtained in a cross section survey that involved 220 shrimp fishers selected using a multistage random sampling procedure in four Local Government Areas of Delta State between July and October, 2010. Applying a Cobb Douglas stochastic production frontier function analysis to the data sets, the results showed that the mean technical efficiency (TE) was 73\% for non motorized shrimp fishers in the study area. The result also showed that boat capacity, nets and labour impacted positively on output of shrimps with nets being significant at $5 \%$ while the technical efficiency of these fishers were positively and significantly related with age, education, access to credit, distance covered and membership of local cooperative groups. Results from the analysis showed that the average gross margin and net margin of non motorized small scale shrimp producer per year are N709, 636.67 and N619, 086.33 respectively while the return on sale was 0.37 , return on investment was $265 \%$ and operating ratio was 0.39 indicating high profitability of shrimp fishing enterprise in the study area. In order to improve the technical efficiency, profitability and income of artisanal shrimp producers, Government needs to initiate and implement policies aimed at the provision of subsidized inputs (nets boats, and outboard engines), improve access to credit, encourage local cooperative group formation and regulate and enforce relevant laws to control water bodies pollution and environmental degradation.
\end{abstract}

Keywords: Technical efficiency, Cobb Douglas Stochastic production frontier, shrimp production,

\section{Introduction}

Shrimps are among the most important living resources in Nigeria's estimated $853 \mathrm{~km}$ coastline and $210,900 \mathrm{~km}^{2}$ marine water including a 200 nautical miles Exclusive Economic Zone (EEZ) in which she has exclusive right to fish and other natural resources (Sogbesan et al, 2006; Chemonics, 2002; and CEHRD, 2007). Nigeria shrimp fishing industry is based on capture not culture and an average of 12,000 tons of shrimps are produced annually in Nigeria (Chemonics, 2002). Shrimps are heavily fished in the creeks and marine waters by the non motorized small scale shrimp fishers between 0 to 5 nautical miles. Shrimps caught are consumed internally and/or sold to earn income. In coastal communities in Delta State, majority of rural households live in abject poverty and deteriorating economic conditions and derive their sources of livelihood from fishing, shrimp production and other fish related activities especially the women and youths. As a result shrimp production is of both commercial and economic importance to the rural coastal people. Studies show that growth in the rural sector has been estimated at 4.0 percent as against 3.0 percent for urban sector (Amos, 2007a). Therefore the rural coastal communities in Delta State offer a great potential to alleviate poverty, generate employment and earn income on a sustainable basis. This potential can only be achieved if productivity and efficiency are increasing and this requires an understanding of the current efficiency or inefficiency inherent in artisanal shrimp production as well as factors responsible for this level of efficiency or inefficiency.

It is against this backdrop that this study aims at analyzing the technical efficiency and its determinants as well as the costs, returns and profitability of small scale non motorized shrimp fishers in the coastal areas of Delta State.

\section{Materials and Methods}

The study was conducted in the coastal areas of Delta State which consists of 8 local government areas (LGAs) namely: Bomadi, Burutu, Isoko North, Isoko South, Patani, Warri North, Warri South and Warri South West. Multistage random 
sampling procedure was used in the collection of the primary data utilized in this study from four LGAs namely Bomadi, Burutu, Warri South West and Warri North in the study area. Fifty five non motorized small scale shrimp fishers were randomly selected from each of the sampled coastal LGA. This gave a total of 220 respondent shrimp fishers that were selected and interviewed for the study.

Model Specification: The stochastic frontier production function was used to analyze technical efficiency and its determinants of shrimp producers in the study area. According to Aigner et al., (1977), extended by Battese and Coelli (1995) and Bhattacharya (2008), the production technology of the shrimp fishers was assumed to be specified by the Cobb - Douglas frontier production function, which is defined by

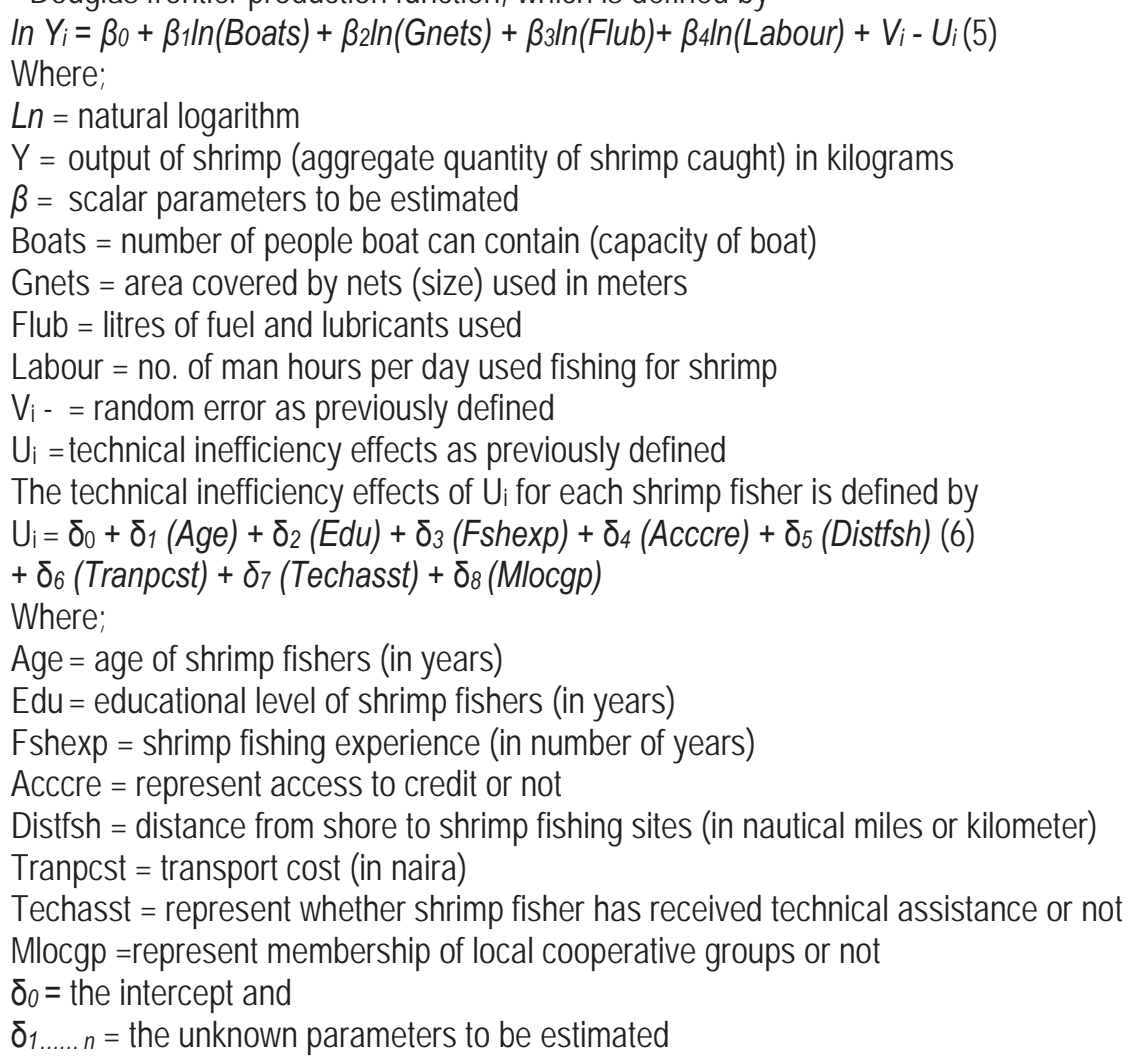

These factors are included in the model to indicate their possible influence on the technical efficiencies of the shrimp fisher. The variances of the random errors $\sigma^{2} v$ and that of the technical inefficiency effects $\sigma^{2} u$ and overall variance of the model $\sigma^{2}$ are related thus:

$\sigma^{2}=\sigma^{2} v+\sigma^{2} u$ and the ratio $\gamma=\frac{\sigma^{2} m u}{\sigma_{v}^{2}+\sigma_{u}^{2}}$ measures the total variation of output from the frontier which can be attributed to technical inefficiency (Batesse and Corra 1977). The estimates for all the parameters of the stochastic frontier production function and the inefficiency model are simultaneously obtained using program frontier 4.1 (Coelli, 1994)

In this study, two different models, Ordinary Least Square (OLS) and the Maximum Likelihood Estimate (MLE) were estimated for the study area.

Model 1: the OLS is the traditional response function in which the inefficiency effects are not present. It is a special case of the stochastic frontier production function in which there is restriction and the total variation of output from the frontier output due to technical inefficiency is zero, that is $y=0$.

Model 2: the MLE on the other hand, is the general model where there is no restriction, hence $\gamma \neq 0$. The 2 models were compared for the presence of technical inefficiency effects using the generalized likelihood ratio test.

The gross margin (GM) and net income (NI) analysis were used to analyze the cost, revenue and profitability of the small scale shrimp producers in the study area.

TC=TVC + TFC
$\pi=$ TR - TC
GM = TR - TVC 
$\mathrm{NI}=\mathrm{GM}-\mathrm{TFC}$ (depreciation)

Where:

$\pi=$ Profit

TR = Total Revenue of shrimp fisher

$\mathrm{TC}=$ Total Cost

TVC $=$ Total Variable Cost

TFC = Total Fixed Cost (depreciation)

$\mathrm{GM}=$ Gross Margin.

$\mathrm{NI}=$ Net Income

Three profitability indicators (return on sale, rate of return on investment and operating ratio) were computed to authenticate the profitability and viability of the small scale shrimp fisher's enterprise.

Return on sale $=\frac{N I}{T R}$

Rate of return on investment (\%) $=\frac{N I * 100}{T C}$ Operating ratio $=\frac{T V C}{T R}$

Where NI, TR, TC, TVC, TR, TFC have been defined above.

\section{Results and Discussion}

Small scale non motorized shrimp fishers in the study area are made up of male and female producers using planked or dugout canoe propelled by paddle and sails with mostly conical basket nets or stow nets and twines, floats, sinks and anchors to fish for shrimps in creeks and river mouths. With an average of 2 to 4 persons per boat, they fish at a distance of between 0 and 3 nautical miles (or 0 to 5 kilometers) mostly between March and December each year. Their shrimp catches are dominated by the estuarine prawns (cray fish) and penaeus notialis (pink shrimps) which are consistent with other studies by CEHRD, 2007; and Sogbesan et al, 2006. On the socio-economic characteristics of the shrimp fishers, the result of the survey showed that male comprised $58 \%$ (127) of all the surveyed respondents while women were $42 \%$ (93). This result showed that small scale non-motorized shrimp production is dominated by women and these findings are consistent with results of other studies by Verstralen and Isebor, 1997; and CEHRD, 2007. The result of the survey also showed that most of the surveyed respondents (70\%) are middle aged (31 - 50 years) suggesting that shrimp fishers are young with vigour and agility required for shrimp fishing activities. The result of other socio-economic indicators showed that $75 \%$ of the surveyed respondent had no education or primary education which is consistent with lack of education in the riverine communities and this impact negatively on the efficiency of small-scale fisher-folks (Inoni, 2006). In terms of experience, the result of the survey indicates that $44 \%$ of the surveyed respondents had less than 11 years fishing experience while 56\% had over 11 years fishing experience. This showed that the respondents had some level of experience which is required for any fishing or business enterprise to ensure increased productivity.

Technical Efficiency Analysis: Table 1 showed that the mean technical efficiency of the non motorized small scale shrimp fishers in the study area is $73 \%$. This indicates that shrimps fishers could increase production by $27 \%$ by improving their technical efficiencies at the artisanal level. This result is in consonance with earlier studies on the technical efficiency of artisanal fishing household in Tanzania (Sesabo and Tol, 2007).

Determinants of Technical Efficiency: The ordinary least square (OLS) and the maximum likelihood estimates (MLE) of the stochastic frontier production function for the non motorized small-scale shrimp fishers in the study area are presented in Table 2. 
Table 1: Estimates of stochastic production frontier by Ordinary Least Square (OLS) and Maximum Likelihood (MLE) and inefficiency functions of the Non Motorized Shrimp Fishers

\begin{tabular}{|c|c|c|c|}
\hline \multirow[t]{2}{*}{ Explanatory variables } & \multirow[t]{2}{*}{ Parameters } & \multicolumn{2}{|c|}{ Non Motorized } \\
\hline & & OLS & MLE \\
\hline \multicolumn{4}{|l|}{ General model } \\
\hline Constant & $\beta_{0}$ & $\begin{array}{l}-0.457 \\
(-1.101)\end{array}$ & $\begin{array}{c}0.583 \\
(1.372)\end{array}$ \\
\hline Boat capacity & $\beta_{1}$ & $\begin{array}{l}-0.011 \\
(-0.038)\end{array}$ & $\begin{array}{c}0.008 \\
(0.034)\end{array}$ \\
\hline Nets used & $\beta_{2}$ & $\begin{array}{c}0.395 \\
(2.979)^{*}\end{array}$ & $\begin{array}{c}0.251 \\
(2.085)^{\star \star}\end{array}$ \\
\hline Labour use & $\mathrm{B}_{3}$ & $\begin{array}{c}0.348 \\
(2.383)^{\star \star}\end{array}$ & $\begin{array}{l}0.104 \\
(0.774)\end{array}$ \\
\hline \multicolumn{4}{|l|}{ Diagnosis statistics } \\
\hline Sigma square $\left(\delta^{2}=\delta_{v}^{2}+\delta_{\mu^{2}}\right)$ & $\delta^{2}$ & 0.267 & $\begin{array}{c}0.212 \\
(6.669)^{*}\end{array}$ \\
\hline Gamma $\left(y=\delta^{2} / \delta_{v^{2}}+\delta_{\mu^{2}}\right)$ & $\Gamma$ & 0.710 & $\begin{array}{c}0.692 \\
(6.380)^{*}\end{array}$ \\
\hline $\begin{array}{l}\text { Log likelihood function } \\
\text { Likelihood ratio }\end{array}$ & L/f & -100.877 & $\begin{array}{l}-71.682 \\
58.390^{*}\end{array}$ \\
\hline $\begin{array}{l}\text { Mean Technical Efficiency } \\
\text { Observation }\end{array}$ & LR & & $\begin{array}{c}72.7(73 \%) \\
220\end{array}$ \\
\hline
\end{tabular}

(Figures in parenthesis are t values)

There was the presence of technical inefficiency effects in shrimp production in the study area as confirmed by a test of hypothesis for inefficiency effects, using the generalized likelihood ratio test. The chi square computed was 58.39 while the critical value of the chi square at $95 \%$ confidence level and 8 degrees of freedom, $X^{2}(0.95,8)$ was 15.51 . The null hypothesis of no inefficiency effect in shrimp production, $y=0$ was rejected. The OLS model was not an adequate representation of the data. Hence, MLE model was the preferred model for further econometric and economic analysis.

The generalized likelihood ratio (LR) test of 58.39 reported in Table 1 is highly significant and this suggests that there is the presence of one sided error component. It means the effect of technical inefficiency was significant and a classical regression model of production function was an inadequate representation of the data.

The MLE result in Table 1 revealed that in the slope coefficient of nets used has the highest elasticity $(0.251)$ followed by that of labour use (0.104) and boat capacity (0.008). Also, all the coefficients of boat capacity, nets used and labour use are positive and increases shrimps output. The impact of net was not only positive but statistically significant at $5 \%$ probability level to the value of shrimps output, indicating that a $5 \%$ increase in the size of nets use will increase shrimps output by $25 \%$.

The variance ratio defined as gamma $(\mathrm{Y})$ was estimated at 0.692 suggesting that systematic influences that are unexplained by the production function are the dominant source of random errors and about $69.2 \%$ of the variation in shrimp output among non motorized shrimp fishers in the study area was due to differences in their technical efficiencies.

\section{Technical Inefficiency Analysis}

Factors determining technical efficiencies of non motorized shrimp fishers are presented in Table 2. Results showed that the coefficients of education (-0.651), credit $(-0.058)$ and membership of local group $(-0.235)$ are negative and statistically significant at $1 \%$ probability level, while coefficient of distance covered $(-0.678)$ to shrimp sites was also negative and statistically significant at $5 \%$ probability level in reducing the level of technical inefficiency. 
Table 2: Factors Determining Technical Efficiency of Non Motorized Shrimp Fishers.

\begin{tabular}{lccc}
\hline Explanatory Variables & Parameters & OLS & MLE \\
\hline Inefficiency model & & & \\
Age of shrimp fisher (years) & $\delta_{1}$ & 0 & 0.634 \\
Education (years) & $\delta_{2}$ & 0 & -0.651 \\
& & & $(-4.532)^{\star}$ \\
Fishing experience (years) & $\delta_{3}$ & 0 & -0.113 \\
Access to credit & $\delta_{4}$ & 0 & -0.0563 \\
Distance to shrimp fishing sites (Nkm) & & & $(-3.214)^{\star}$ \\
Transport cost (naira/day) & $\delta_{5}$ & 0 & -0.678 \\
Technical assistance & $\delta_{6}$ & 0 & $-0.079)^{\star *}$ \\
Member of local group & & & $(-1.354)$ \\
\hline
\end{tabular}

* significant at1\% level, ${ }^{* \star}$ significant at $5 \%$ level. (Figures in parenthesis are t values)

The result of education which can be used as a proxy for managerial input showed that shrimp fishers with better education were technically more efficient than their counterpart with less education because it enhances the fisher's ability to seek, interpret and make good use of information and production inputs. In the case of credit, the result indicate that shrimp fishers that have access to credit to procure critical inputs required for increased shrimp productivity were more technically efficient than their counterparts who had no access to credit. This finding is similar to that of Frito and Curtis (2008) and Parikh et al (1995) who found that household who use credit were more efficient.

The positive and significant relationship between affiliation to local cooperative groups and technical efficiency implies that members of the shrimp cooperative groups tend to be more efficient because they have better access to knowledge, inputs and credit than non-members. This result is similar to Amos (2007b), who found that group membership contributed to technical efficiency. This finding clearly underscores the role of organizational membership in increasing productivity. Other technically inefficiency reducing factors with negative coefficients that are not statistically significant are fishing experience $(-0.113)$, transport cost $(-0.203)$ and technical assistance through extension agents (0.036).

Contrary to apriori expectation, age is the only factor with positive coefficient (0.634) and statistically significant at $5 \%$ probability level in reducing the level of technical efficiency (increasing inefficiency) among the non motorized shrimp fishers and this finding is similar to that of Abdulai and Eberlin (2001) and Amos (2007a). This can be explained by the fact that although shrimp fishers become more skilful as they get older, the knowhow is attenuated as they approach their middle age, as their physical strength begins to decline thus resulting in decreasing productivity and technical efficiency. Also, older farmers are less likely to have contacts with extension agents and are less willing to adopt new practices and modern inputs.

\subsection{Costs, revenue and profitability structures of Small scale shrimp fishers}

The cost, revenue and profit structures for non motorized small scale shrimp fishers are presented in Table 3 . The cost analysis showed that the average total cost per non motorized shrimp fisher was N248, 065.92, made up of variable cost of N157, 514.98 and fixed costs N90, 550.94. The major variable cost items were labour and food accounting for $51 \%$ and $24 \%$ respectively. The cost of labour was high because of alternative sources of employment in oil and dredging companies in the area under consideration. Like other small scale fishing enterprises, the most critical fixed cost items are boats/canoes and nets accounting for $44 \%$ and $29 \%$ of fixed cost component (Ceregato and Petrere, 2003; Inoni, 2006).

The revenue obtained by the shrimp fishers is a function of the number of days of fishing, quantities of shrimp caught and the market price per kilogram. Table 3 showed that total revenue earned per year per non motorized fisher was N867, 151.65 (N5, 223.81 per day).

The average gross margin and net margin for the non motorized shrimp fisher per year are N709, 636.67 and 
N619, 086.33 respectively. Therefore on a daily basis, the profit of the non motorized small scale shrimp fisher was N3, 729.44 which is consistent with the result of CEHRD (2007) that a local shrimp producer operating in the creeks and rivers earn profit and makes between N2, 813 and N7, 875 per day; and that of Ceregato and Petrere (2003), who found out that artisanal fishing is profitable and fishers makes a daily profit of N1, 524.20 to N1, 701.50 in the Middle Parana River in Brazil.

Table 3: Cost and return structure of non motorized small scale shrimp fishers (Naira)

\begin{tabular}{|c|c|c|}
\hline Cost/Revenue Structure & Average & Percentage (\%) \\
\hline \multicolumn{3}{|l|}{ Revenue } \\
\hline Average days fishing (nos) ${ }^{\star}$ & 166 & \\
\hline Average quantity of shrimps caught per day (kg) & 18.04 & \\
\hline Average price per kg (naira) & 285.46 & \\
\hline Average revenue per year (naira) & $867,151.65$ & \\
\hline Revenue per day (naira) & $5,223.81$ & \\
\hline Total revenue & $867,151.65$ & \\
\hline \multicolumn{3}{|l|}{ Variable cost } \\
\hline Repair and maintenance & $17,817.35$ & 11.31 \\
\hline Food & $38,568.64$ & 24.49 \\
\hline Labour cost & $79,773.64$ & 50.65 \\
\hline Miscellaneous & $21,355.36$ & 13.55 \\
\hline Total variable cost & $157,514.98$ & 100.0 \\
\hline \multicolumn{3}{|l|}{ Fixed Cost (Depreciation) } \\
\hline Boats & $39,499.09$ & 43.62 \\
\hline Nets & $26,496.25$ & 29.26 \\
\hline Accessories & $24,555.60$ & 27.12 \\
\hline Total fixed costs (TFC) & $90,550.94$ & 100.00 \\
\hline Total cost & $248,065.92$ & \\
\hline Gross Margin (GM) & $709,636.67$ & \\
\hline Net margin & $619,086.33$ & \\
\hline Net margin or profit per day (naira) & $3,729.44$ & \\
\hline \multicolumn{3}{|l|}{ Profitability Indicators } \\
\hline Return on sale (proportion) & & 0.37 \\
\hline Rate of return on investment (\%) & & 265.10 \\
\hline Operating ratio (naira) & & 0.39 \\
\hline
\end{tabular}

*Fishing takes place on the average of 16 days per month

Source: Computed from survey data, 2010

The return to sale, rate of return on investment and operating ratio of the shrimp fisher are also presented in Table 3. The return on shrimp sale is 0.37 which implies that in the study area, profit was $37 \%$ of the gross revenue on the average while the rate of return on investment and operating ratio are 265.10 and 0.39 signifying N2.65 accrued to the shrimp fishers for every naira invested in shrimp production. The operating ratio indicates that the total variable cost was $39 \%$ of the total revenue. In summary all the profitability indicators showed that non motorized small scale shrimp enterprise is profitable in the study area and confirm results of previous studies in the artisanal fisheries sectors (CEHRD, 2007; Inoni, 2006; Ceregator and Petrere, 2003; Kurien and Willmann, 1982; Ojo and Ogundari, 2008; and Baharanji et al, 2006).

\section{Conclusion and Recommendations}

The study showed that the mean technical efficiency of non motorized shrimp fishers was $73 \%$ and that on the average there is a great opportunity for these fishers to increase their level of efficiency in shrimp production. Also, the technical efficiency of the non motorized small-scale shrimp fishers was positively and significantly related with education, access to credit, distance covered and membership of local cooperative groups but negatively related to age. Also small scale shrimp production business is a profitable enterprise. In order to improve the technical efficiency, profitability and income of small scale shrimp fishers, Government should be encouraged to implement policies aimed at the provision of subsidized inputs (nets boats, and outboard engines), improve access to credit, encourage local cooperative group formation and regulate and enforce relevant laws to control water bodies pollution and environmental degradation. 


\section{References}

Abdulai, A. and R. Eberlin (2001). Technical efficiency during economic reform in Nicaragua Evidence from farm household survey data. Econom. Syst., 25(2): 113-125

Aigier, D., C.A.K. Lovell, and P. Schmidt (1977). Formulation and Estimation of Stochastic Frontier Production Function Models, Journal of Econometrics 6:1, 21-37.

Available at: http://www.rand.org/pubs/papers/2008/p5649.pdf. Accessed February 10th, 2009.

Amos T. T. (2007a). Production and Productivity of Crustacean in Nigeria. Journal of Social Science, 15(3): 229-233 2007.

Amos T. T. (2007b). An Analysis of Productivity and Technical Efficiency of Smallholder Cocoa Farmers in Nigeria. Journal of Social Science, 15(2): 127-133.

Baharanyi, N.; B. Vaughan; and A. Deanes (2006). Assessing the Viability of the Inland Shrimp Farming as a Viable Entreprise in Alabama. Sustainable Agriculture Research and Education. SARE Reporting System: GS04-036: 2006 Final Report. Available at: http://www.sare.org/reporting/report. Accessed 6th June, 2009.

Battese, G. E.; and T. J. Coelli. (1995). "A Model for Technical Inefficiency Effects in a Stochastic Frontier Production Function for Panel Data," Empirical Economics, Vol.20, pp. 325-332.

Battese, G. E. and G. S. Corra (1977). Estimation of a Production Frontier Model with Application to the Pastoral Zone of Eastern Australia Aust. J. Agri. Eco., $21169-179$.

Bhattacharya, P. (2008). Comparative study of Traditional vs Scientific Shrimp Farming in West Bengal: A Technical Efficiency Analysis. Institute for Social and Economic change, 2008. Available at http://www.isec.ac.in/wp. Accessed on 19th May, 2009

CEHRD (February, 2007)Small Scale Shrimp Fisheries in Nigeria. Report of a field based investigation conducted by the conservation program of Centre for Environment, Human Rights and Development (CEHRD) with support from the World Conservation Union (IUCN), the Netherland. February, 2007

Ceregato, S.A.and M. Jr. Petrere (2003). Financial Comparisons of the Artisanal Fisheries in Urubupunga Complex in the Middle Parana River (Brazil). Braz. J. Biol. Vol. 63 (4): 673-682, 2003. Available at: http://www.scielo.br/pdf/bb/v63n4/19182.pdf. Accessed 25th May, 2009.

Chemonics International Inc.; (November, 2002) Subsector Assessment of the Nigerian Shrimp and Prawn Industry. Prepared for: The United States for International Development (USAID) / Nigeria. RAISE IQC, contract no. PCE-1-00-99-00003-00. Agricultural Development Assistance in Nigeria. Task Order No. 812

Coelli T. J. (1994). A Guide to FRONTIER Version 4.1: Computer Program for Stochastic Frontier Production and Cost Function Estimation, mimeo, Department of Econometrics, University of New England, Armidale.

Frito, D.; and M. J. Curtis. (2008). Technical Efficiency of Traditional and Non-Traditional Crop Production: A Case Study from Haiti. World Journal of Agricultural Sciences 4 (4): 416-426, 2008. ISSN 1871-3047

Halafo JS, Hecky RE and Taylor WD (2004). The artisanal Fishery of Metangula, lake Malawi/Niassa, East Africa. African Journal of Aquatic Science 29(1):83-90

Inoni, O. E. (2006). Socio-economic Analysis of Artisanal Fisheries Resources Exploitation in Delta State, Nigeria. PhD Dissertation, Delta State University, Abraka

Kurien, J.; and Willmann, R. (1982). Economic of Artisanal and Mechanized Fisheries in Kerala: A Study of Costs and Earnings of Fishing Units. Small Scale Fisheries Promotion in South Asia. RAS/77/044. A Regional FAO/UNDP Project. Working Paper No. 34. July 1982.

Ojo, S.O and Ogundari (2008). Fighting Poverty and Unemployment with Efficient Fish Farming in Nigeria. Available at http://www.tropentag.de/2008/abstracts/links/Ojo_cJu06m Lo.pdf. Accessed 28th August, 2009.

Parikh, A., F. Ali and M. K. Shah, (1995). Measurement of economic efficiency in Pakistan agriculture. American Journal of Agric. Economics, 77:675-685

Sesabo, J. K; R. S. J. Tol. (2007). Technical efficiency in small-scale fishing households in Tanzania coastal villages: An empirical analysis. Available at: http://www.mi.uni-hamburg.de/fileadmin/fnu-files/models.data/FNU95.pdf. Accessed 10th February, 2009.

Sogbesan, A. O.; T. Oluwasegun and L. M. O. Ibiyo. (2006) Shell Fish Farming in Nigeria: Aquaculture Potential and Investment Opportunities Projections. American-Eurasian Journal. Agric. \& Environ. Sci., 1 (2): 106-112, 2006

Verstralen, K; C. Isebor (1997). Costs, Earnings, and Expenditure Structures of Fisherwomen, Fish Processors, and Fish Traders in Ogheye, Delta State, Nigeria. Programme for the Integrated Development of Artisanal Fisheries in West Africa, Cotonou, Benin, 36, IDAF/WP/108. 